\title{
The Potential of Molybdenum Complexes Bearing Unsubstituted Heterodiatomic Group 15 Elements as Linkers in Supramolecular Chemistry
}

\author{
Mehdi Elsayed Moussa, Michael Seidl, Gábor Balázs, Matthias Hautmann, and Manfred Scheer*
}

Dedicated to Professor E. Niecke on the occasion of his 80th birthday

\begin{abstract}
The reactions of tetrahedral molybdenum complexes bearing unsubstituted heterodiatomic Group 15 elements, $\left[C p_{2} \mathrm{Mo}_{2}(\mathrm{CO})_{4}\left(\mu, \eta^{2}: \eta^{2}-\mathrm{PE}\right)\right] \quad\left(\mathrm{Cp}=\mathrm{C}_{5} \mathrm{H}_{5} ; \quad E=A s \quad(\boldsymbol{1}), \quad S b\right.$ (2)), with $C u^{I}$ halides afforded seven unprecedented neutral supramolecular assemblies. Depending on the $\mathrm{Mo}_{2} \mathrm{PE}$ units and the $\mathrm{Cu}{ }^{I}$ halide, the oligomers $\quad\left[\left\langle\mathrm{CP}_{2} \mathrm{Mo}_{2}\right.\right.$ $\left.\left.\left.(C O)_{4}\right\}\left\{\mu_{4}, \eta^{2}: \eta^{2}: \eta^{2}: \eta^{1}-P E\right\}\right\rangle_{4}\langle\{C u X\}\{C u(\mu-X)\}\rangle_{2}\right] \quad(E=A s$ $(X=C l(3), B r(4)) ; E=S b(X=C l(6), B r(7)))$ or the $1 D$ coordination polymers $\left[\left\{C p_{2} M_{2}(C O)_{4}\right\}\left\{\mu_{4}, \eta^{2}: \eta^{2}: \eta^{1}: \eta^{1}-P A s\right\}\right.$ $\{C u(\mu-I)\}]_{n}(5)$ and $\left[\left\{C p_{2} M_{2}(C O)_{4}\right\}\left\{\mu_{4}, \eta^{2}: \eta^{2}: \eta^{2}: \eta^{1}-P S b\right\}_{2}\{C u-\right.$ $\left.(\mu-X)\}_{3}\right]_{n}(X=I(8), B r(\mathbf{9}))$ are accessible. These solid-state aggregates are the first and only examples featuring the organometallic heterodiatomic $\mathrm{Mo}_{2} \mathrm{PE}$ complexes 1 and 2 as linking moieties. DFT calculations demonstrate that complexes 1 and $\mathbf{2}$ present a unique class of mixed-donor ligands coordinating to $C u^{I}$ centers via the $P$ lone pair and the $P-E$ $\sigma$-bond, revealing an unprecedented coordination mode.
\end{abstract}

For proved to be a simple yet effective strategy for the facile construction of well-defined solid-state structures. ${ }^{[1]}$ Using this method, a large variety of discrete assemblies and multidimensional arrays have been designed by skillful selection of multitopic organic linkers to connect coordinatively unsaturated metal centers. The ligands employed are most commonly $\mathrm{N}$ - or O-donor-containing organic molecules $^{[1 \mathrm{~b}]}$ whereas S-, Se-, and P-donor-containing compounds are less common. ${ }^{[2]}$ Moreover, few examples of $(\mathrm{P}, \mathrm{N}),(\mathrm{N}, \mathrm{O})$, $(\mathrm{P}, \mathrm{S})$, and other mixed-donor ligands are known to also link different metal centers. ${ }^{[3]}$ Compared to organic molecules, organometallic building blocks have only very rarely been involved as connectors in supramolecular chemistry. ${ }^{[4]}$ For that reason, our group developed the concept of using organometallic complexes bearing "naked" polyphosphorus $\left(\mathrm{P}_{n}\right)$ donor atoms as connectors between metal ions. ${ }^{[5]}$ These compounds possess very flexible coordination modes, which

[**] Dr. M. Elsayed Moussa, Dr. M. Seidl, Dr. G. Balázs, M. Hautmann, Prof. Dr. M. Scheer

Institute für Anorganische Chemie der Universität Regensburg 93040 Regensburg (Germany)

E-mail: manfred.scheer@chemie.uni-regensburg.de

Homepage: https://www.uni-regensburg.de/chemie-pharmazie/ anorganische-chemie-scheer

(2) Supporting information and the ORCID identification number(s) for the author(s) of this article can be found under: https://doi.org/10.1002/anie.201907067. allow the synthesis of a large library of discrete (monomers, ${ }^{[6 b, c]}$ dimers, ${ }^{[6 a, b, d]}$ spherical aggregates, ${ }^{[7]}$ nanobowls, ${ }^{[8]}$ and nanosized capsules $\left.{ }^{[9]}\right)$ and polymeric $(1 \mathrm{D}, 2 \mathrm{D}$, and $3 \mathrm{D}$ coordination polymers $(\mathrm{CPs}))^{[\mathrm{6a}, 10]}$ supramolecular assemblies in moderate to excellent yields. Interestingly, few of these $\mathrm{P}_{n}$ compounds could be further involved in three-component reactions together with $\mathrm{Ag}^{\mathrm{I}}$ or $\mathrm{Cu}^{\mathrm{I}}$ salts and ditopic $\mathrm{N}$-donor organic molecules to afford unprecedented organometallicorganic hybrid polymers. ${ }^{[1]}$ In contrast to the rather large number of assemblies based on $\mathrm{P}_{n}$-ligand complexes, few aggregates have been reported by ourselves and others featuring $\mathrm{As}_{n}{ }^{-[12]}$ and $\mathrm{Sb}_{n}$-ligand complexes, ${ }^{[13]}$ respectively, as building blocks. These $\mathrm{E}_{n}$-ligand complexes show coordination behaviors towards metal ions that differ from that of their $\mathrm{P}_{n}$-ligand analogues, paving the way for new advances in the supramolecular chemistry of softer Lewis bases.

In view of these initial results concerning homoatomic linkers, the question arose as to which coordination mode would establish mixed $\mathrm{P}_{n} \mathrm{E}_{m}$-donor complexes $(\mathrm{E}=\mathrm{As}, \mathrm{Sb})$ to potentially reach a new level of insight into their coordination behavior. In fact, because of the hindered accessibility of the lone pair of the heavier congeners of phosphorus, such $\mathrm{P}_{n} \mathrm{E}_{m}$ complexes were expected to have very different coordination behaviors compared to homoatomic $\mathrm{P}_{n}$ or $\mathrm{E}_{n}$ compounds. Additionally, we were also facing the fact that, in general, very rarely (P,As) mixed-donor compounds ${ }^{[14]}$ and no examples of $(\mathrm{P}, \mathrm{Sb})$ compounds have been used as linking moieties between metal ions. We report herein the first examples of supramolecular aggregates featuring the tetrahedral heterodiatomic Group 15 complexes $\left[\mathrm{Cp}_{2} \mathrm{Mo}_{2}(\mathrm{CO})_{4}\left(\mu, \eta^{2}: \eta^{2}-\mathrm{PE}\right)\right]$ $(\mathrm{E}=\mathrm{As}(\mathbf{1}), \mathrm{Sb}(\mathbf{2}))$ as linkers in supramolecular chemistry. Moreover, their X-ray structures and DFT calculations show that these compounds represent a unique type of donor ligand as they coordinate to unsaturated $\mathrm{Cu}^{\mathrm{I}}$ ions via the $\mathrm{P}$ lone pair and the $\mathrm{P}-\mathrm{E} \sigma$-bond.

In order to evaluate the bonding situation in complexes $\mathbf{1}$ and $\mathbf{2}$ towards the unsaturated $\mathrm{Cu}^{\mathrm{I}}$ centers, we performed DFT calculations at the B3LYP/def2TZVP level of theory. The results show that the lone pairs of the As and Sb atoms are lower in energy than that of the P atom (Figure 1a). More pronounced is, however, the increase in energy of the $\mathrm{P}-\mathrm{E}$ $\sigma$-bond for the heavier congeners, which allows for a more effective overlap of these orbitals with the unoccupied orbitals of $\mathrm{Cu}$, instead of the lone pair. This indicates that for heavier congeners, the $\mathrm{P}-\mathrm{E} \sigma$-bond should be involved in the bonding with unsaturated transition-metal fragments. 
a)

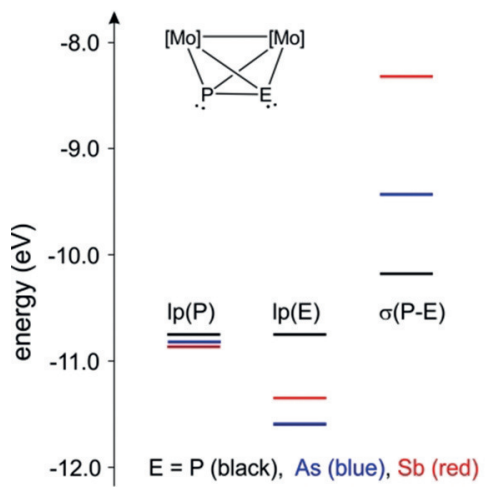

b)
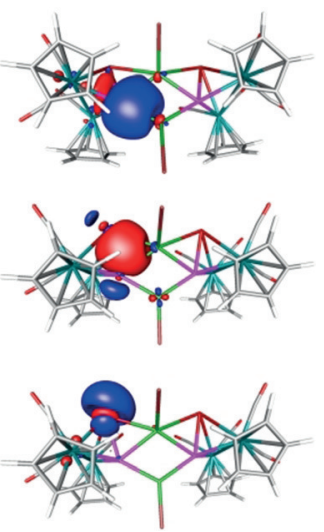

Figure 1. a) Frontier orbital energy diagram of $\left[\mathrm{Cp}_{2} \mathrm{Mo}_{2}(\mathrm{CO})_{4}\left(\mu, \eta^{2}-\mathrm{PE}\right)\right]$ $(E=P, A s$, and $S b)$, calculated at the B3LYP/def2-TZVP level of theory. b) One set of the localized molecular orbitals in 7 representing the coordination of the $\mathrm{P}$ lone pair (top), the $\mathrm{P}-\mathrm{Sb} \sigma$-bond (middle), and the lone pair of Sb (bottom).

Inspired by these calculations, the ligand complex $\mathbf{1}^{[15]}$ was initially reacted with the $\mathrm{Cu}^{\mathrm{I}}$ salts $\mathrm{CuCl}, \mathrm{CuBr}$, and $\mathrm{CuI}$ in a 1:1 stoichiometric ratio in a mixture of $\mathrm{CH}_{2} \mathrm{Cl}_{2}$ and $\mathrm{CH}_{3} \mathrm{CN}$ at room temperature (Figure 2a). These reactions afforded the neutral oligomeric complexes $\left[\left\langle\left\{\mathrm{Cp}_{2} \mathrm{Mo}_{2}{ }^{-}\right.\right.\right.$ $\left.\left.\left.(\mathrm{CO})_{4}\right\}\left\{\mu_{4}, \eta^{2}: \eta^{2}: \eta^{2}: \eta^{1}-\mathrm{PAs}\right\}\right\rangle_{4}\langle\{\mathrm{CuX}\}\{\mathrm{Cu}(\mu-\mathrm{X})\}\rangle_{2}\right] \quad(\mathrm{X}=\mathrm{Cl} \quad(3)$, $\mathrm{X}=\mathrm{Br}(4))$ as well as the neutral $1 \mathrm{D} \mathrm{CP}\left[\left\{\mathrm{Cp}_{2} \mathrm{Mo}_{2}\right.\right.$ (CO) $\left.)_{4}\right\}\left\{\mu_{4}, \eta^{2}: \eta^{2}: \eta^{1}: \eta^{1}\right.$-PAs $\left.\}\{\mathrm{Cu}(\mu-\mathrm{I})\}\right]_{n}$ (5) in excellent yields $(86-92 \%)$. Interestingly, these compounds are air- and lightstable in the solid state for several days while they show decomposition within hours in solutions of $\mathrm{CH}_{3} \mathrm{CN}$ under air. Compounds 3-5 are insoluble in most common organic solvents, and are only soluble in trace amounts of donor solvents such as $\mathrm{CH}_{3} \mathrm{CN}$ without complete dissociation into their building blocks, as evidenced by ${ }^{31} \mathrm{P}$ NMR spectroscopy.

Single crystals of products 3 (orange plates), $\mathbf{4}$ (red blocks), and $\mathbf{5}$ (orange rods) were characterized by X-ray crystallography (Figure 2b, c; Table S1 in the Supporting Information). Their structures display similar tetrameric cores for $\mathbf{3}$ and $\mathbf{4}$ and a polymeric core for $\mathbf{5}$. Each of the molecules $\mathbf{3}$ and $\mathbf{4}$ consists of four $\mathrm{Mo}_{2} \mathrm{PAs}$ units $\mathbf{1}$ and four $\mathrm{CuX}(\mathrm{X}=\mathrm{Cl}(\mathbf{3}), \mathrm{Br}$ (4)) moieties. Within these compounds, all ligands $\mathbf{1}$ are similar, each adopting a $\eta^{2}: \eta^{1}$-coordination mode, which is the most favored coordination mode according to the DFT calculations. Within these compounds, there are two types of $\mathrm{Cu}$ (central $\mathrm{Cu}$ (in) and peripheral $\mathrm{Cu}$ (out)) and halide (terminal $\mathrm{X}($ ter $)$ and bridging $\mathrm{X}(\mathrm{br})$ ) ions. The $\mathrm{Cu}$ (in) ions are each pentacoordinated to two $\mathrm{P}$ atoms, two $\mathrm{X}^{-}$ions, and one $\mathrm{Cu}^{\mathrm{I}}$ ion, while the $\mathrm{Cu}$ (out) ions are each hexacoordinated to two $\mathrm{P}$ atoms, two As atoms, one $\mathrm{Cu}^{\mathrm{I}}$ ion, and one $\mathrm{X}^{-}$ion. The $\mathrm{Cu}$ (in) $\cdots \mathrm{Cu}$ (out) distances between two neighboring $\mathrm{Cu}$ (in) and $\mathrm{Cu}$ (out) ions in $\mathbf{3}$ and $\mathbf{4}$ are in the range of about 2.64 to $2.69 \AA$, and thus shorter than the sum of their van der Waals radii $(2.80 \AA)$, revealing possible $\mathrm{Cu} \cdots \mathrm{Cu}$ interactions. ${ }^{[16]}$ However, the $\mathrm{Cu}$ (in) $\cdots \mathrm{Cu}$ (in) distances within the $\mathrm{Cu}(\text { in })_{2} \mathrm{X}$ (br $)_{2}$ four-membered rings are in the range of about 3.20 to $3.28 \AA$, revealing no cuprophilic interaction. The structure of 5 reveals a linear $1 \mathrm{D}$ chain consisting of planar fourmembered $\mathrm{Cu}_{2} \mathrm{I}_{2}$ and six-membered $\mathrm{Cu}_{2} \mathrm{P}_{2} \mathrm{As}_{2}$ ring motifs, alternatingly arranged in an orthogonal manner. This structure is similar to that of $1 \mathrm{D}$ CPs obtained from the reaction of its homodiatomic analogue $\left[\mathrm{Cp}_{2} \mathrm{Mo}_{2}(\mathrm{CO})_{4}\left(\mu, \eta^{2}: \eta^{2}-\mathrm{P}_{2}\right)\right] \cdot{ }^{[18]} \mathrm{All}$ of the $\mathrm{Cu}^{\mathrm{I}}$ ions in $\mathbf{5}$ adopt a distorted tetrahedral coordination geometry with one $\mathrm{P}$ atom, one As atom, and two $\mathrm{I}^{-}$ions. In contrast to what was observed in the tetramers $\mathbf{3}$ and $\mathbf{4}$, all of the $\mathrm{Mo}_{2}$ PAs (1) ligands in $\mathbf{5}$ adopt an $\eta^{1}: \eta^{1}$-coordination mode. The $\mathrm{P}-\mathrm{As}$ bond lengths in $\mathbf{3}$ to $\mathbf{5}$ (2.240(4)-2.298(4) A) are comparable to that of the non-coordinated ligand complex 1 (2.232(4) $\AA$ ).$^{[15 b]}$ The $\mathrm{Cu}-\mathrm{P}$ bond lengths are in the range of (2.210(6)-2.293(1) $\AA$ ), and the $\mathrm{Cu}-\mathrm{As}$ bond lengths range a)
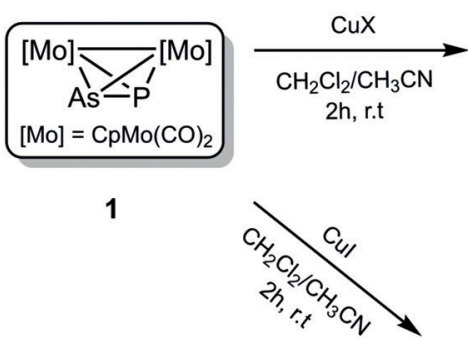

b)

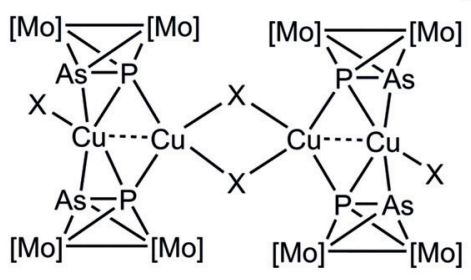

$\mathrm{X}=\mathrm{Cl}(\mathbf{3}), 89 \%$

$\mathrm{Br}(4), 86 \%$

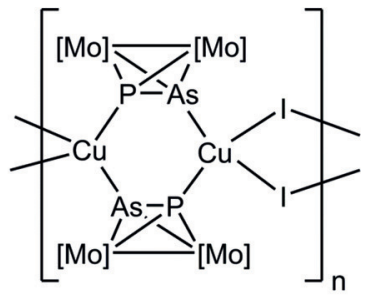

(5), $92 \%$

c)
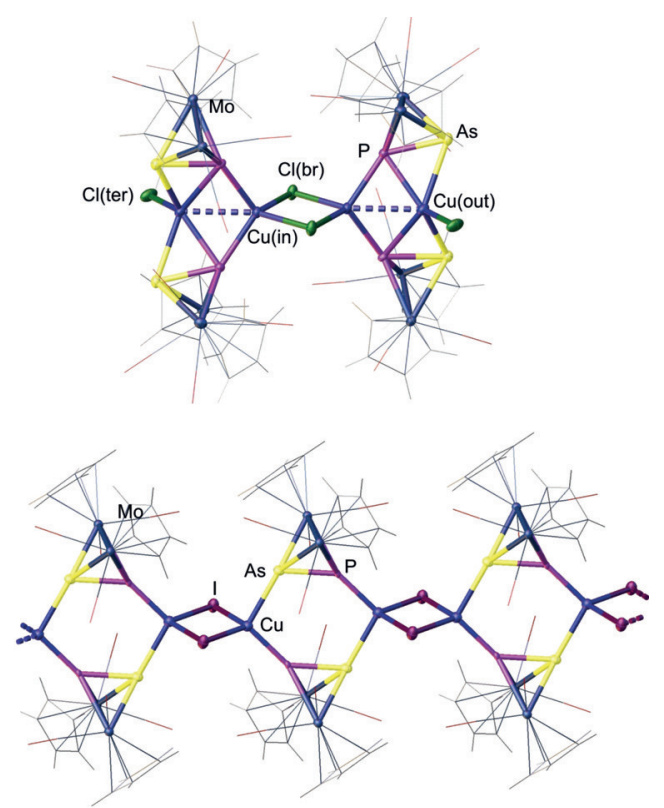

Figure 2. a) Synthesis of compounds 3-5. b) Molecular structure of 3 (4 has a similar structure; see the Supporting Information) in the solid state. c) Section of the 1D polymer $5 .^{[17]}$ 
from 2.461(9) to 2.584(2) $\AA$. The room-temperature ${ }^{31} \mathrm{P}$ NMR spectra of $\mathbf{3}-\mathbf{5}$ in $\mathrm{CD}_{3} \mathrm{CN}$ display single signals for $\mathbf{3}$ (22.1 ppm), 4 (22.9 ppm), and 5 (24.1 ppm), respectively, which are 4 to $6 \mathrm{ppm}$ upfield-shifted compared to that of the free complex $(28.5 \mathrm{ppm})$, thus revealing an incomplete dissociation of these aggregates in solutions of $\mathrm{CH}_{3} \mathrm{CN}$.

Further, the ligand complex $\left[\mathrm{Cp}_{2} \mathrm{Mo}_{2}(\mathrm{CO})_{4}\left(\mu, \eta^{2}: \eta^{2}-\mathrm{PSb}\right)\right]$ (2) was reacted with the $\mathrm{Cu}^{\mathrm{I}}$ salts $\mathrm{CuCl}, \mathrm{CuBr}$, and $\mathrm{CuI}$ under experimental conditions similar to those used for $\mathbf{1}$ (Figure $3 \mathrm{a}$ ). These reactions afforded the neutral oligomeric complexes $\left[\left\{\mathrm{Cp}_{2} \mathrm{Mo}_{2}(\mathrm{CO})_{4}\right\}\left\{\mu_{4}, \eta^{2}: \eta^{2} \eta^{2}: \eta^{1}-\mathrm{PSb}\right\}\right\rangle_{4}\langle\{\mathrm{CuX}\}\{\mathrm{Cu}(\mu-$ $\left.\mathrm{X})\}\rangle_{2}\right](\mathrm{X}=\mathrm{Cl}(\mathbf{6}), \mathrm{X}=\mathrm{Br}(7))$ and the neutral 1D CPs $\left[\left\{\mathrm{Cp}_{2} \mathrm{Mo}_{2}(\mathrm{CO})_{4}\right\}\left\{\mu_{4}, \eta^{2}: \eta^{2}: \eta^{2}: \eta^{1}-\mathrm{PSb}\right\}_{2}\{\mathrm{Cu}(\mu-\mathrm{X})\}_{3}\right]_{n}(\mathrm{X}=\mathrm{Br}(\mathbf{9})$, $\mathrm{X}=\mathrm{I}(\mathbf{8}))$ in moderate to good yields (52-72\%). Unlike 3-5, the adducts 6-9 are air-sensitive and could only be isolated and stored at ambient conditions under an inert atmosphere. Moreover, these compounds are insoluble in common solvents and could only be characterized in the solid state. Their $\mathrm{X}$-ray structures showed that $\mathbf{6}$ and $\mathbf{7}$ are isomorphous and have structures similar to those of $\mathbf{3}$ and $\mathbf{4}$, while $\mathbf{8}$ represents an unprecedented $1 \mathrm{D}$ polymer (Figure $3 \mathrm{~b}, \mathrm{c}$ ).

The coordination environments of all $\mathrm{Cu}$ and halide ions in $\mathbf{6}$ and $\mathbf{7}$ are similar to those found for the tetramers $\mathbf{3}$ and $\mathbf{4}$. The $\left[\mathrm{Cp}_{2} \mathrm{Mo}_{2}(\mathrm{CO})_{4}\left(\mu, \eta^{2}: \eta^{2}-\mathrm{PSb}\right)\right]$ units within these compounds possess each a $\eta^{2}: \eta^{1}$-coordination mode, which was predicted by DFT calculations. The $\mathrm{Cu}$ (in) $\cdots \mathrm{Cu}$ (out) distances in $\mathbf{6}$ and 7 are in the range of about 2.53 to $2.54 \AA$, suggesting possible $\mathrm{Cu} \cdots \mathrm{Cu}$ interactions ${ }^{[16]}$ In contrast to what was observed for all coordination compounds 3-7, the crystal structure of $\mathbf{8}$ indicates that it contains a stoichiometry of the building blocks differing from the one used during the synthesis for the starting materials. Two types of $\mathrm{Cu}$ ions exist in $\mathbf{8}$, the central $\mathrm{Cu}$ (in) and the peripheral $\mathrm{Cu}$ (out) ionss, with the $\mathrm{Cu}$ (in) being hexacoordinated to two $\mathrm{P}$ and two $\mathrm{Sb}$ atoms, and two $\mathrm{Cu}^{\mathrm{I}}$ ions and the $\mathrm{Cu}$ (out) being each pentacoordinated to one $\mathrm{P}$ atom, one $\mathrm{Cu}$ ion, and three $\mathrm{I}^{-}$ ions. The $\mathrm{Cu}$ (in) $\cdots \mathrm{Cu}$ (out) distances are in the range of 2.65 to $2.66 \AA$, thereby revealing possible $\mathrm{Cu} \cdots \mathrm{Cu}$ interactions. ${ }^{[16]}$ Interestingly, the $\mathrm{Cu}$ (out) $\cdots \mathrm{Cu}$ (out) distances within two consecutive $\mathrm{Cu}(\text { out })_{2}(\mu-\mathrm{I})_{2}$ four-membered rings are different from each other (ca. 2.86 and $3.31 \AA$ ); however, both are longer than the sum of their van der Waals radii, revealing no cuprophilic interactions. As a consequence of the short $\mathrm{Cu} \cdots \mathrm{Cu}$ distance between the $\mathrm{Cu}$ (in) and $\mathrm{Cu}$ (out) ions in $\mathbf{8}$, this compound can also be described as an infinite chain of $\mathrm{Cu}_{3}$ repeating units stabilized by two organometallic ligands of 2 and one $\mathrm{I}^{-}$ion, and connected to each other via two $\mu-\mathrm{I}$ ligands. To the best of our knowledge, no such polynuclear $\mathrm{Cu}^{\mathrm{I}}$ chains stabilized by organometallic ligands had previously been reported. ${ }^{[16]}$ The $\mathrm{P}-\mathrm{Sb}$ bond lengths in 6-8 (2.445(8)2.508(3) ^) are comparable to that of the non-coordinated complex $2(2.469(9) \AA) .{ }^{[15 b]}$ The $\mathrm{Cu}-\mathrm{P}$ bond lengths are in the range of 2.280(2) to 2.508(3) $\AA$, and the $\mathrm{Cu}-\mathrm{Sb}$ bond lengths are in between 2.667(4) and 2.771(7) $\AA$.

As the differences in the electronic structures of $\left[\mathrm{Cp}_{2} \mathrm{Mo}_{2}-\right.$ $\left.(\mathrm{CO})_{4}\left(\mu, \eta^{2}: \eta^{2}-\mathrm{P}_{2}\right)\right], \mathbf{1}$, and $\mathbf{2}$ are most accentuated for $\mathbf{2}$, we investigated the electronic structure of complex 7 by DFT calculations (Figure 1b and the Supporting Information). Geometry optimization in the gas phase led to a geometry that is very close to the experimentally found geometry, indicating that this geometry is not a result of the packing effects in the solid state. The $\mathrm{Cu} \cdots \mathrm{Cu}$ distance of $2.593 \AA$ in the optimized geometry is only slightly longer than the experimental value of 2.534(4) $\AA$. The bonding between the two units of 2 and $\mathrm{CuBr}$ in $\mathbf{7}$ can best be described as being built up from a coordination of the $\mathrm{P}$ lone pair to $\mathrm{Cu}$ (in) and a coordination of the $\mathrm{P}-\mathrm{Sb} \sigma$-bond in $\mathbf{2}$ to the $\mathrm{Cu}$ (out) atom. This is confirmed by the localized molecular orbitals depicted a)

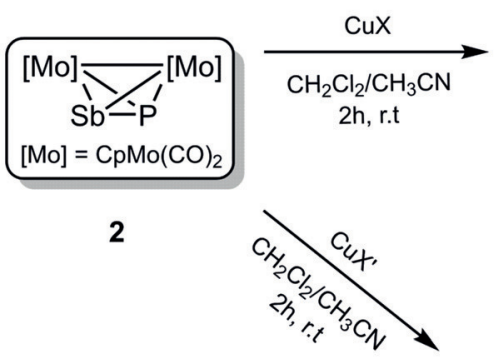

b)

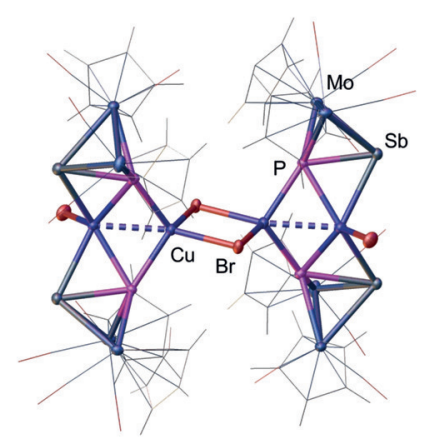

c)

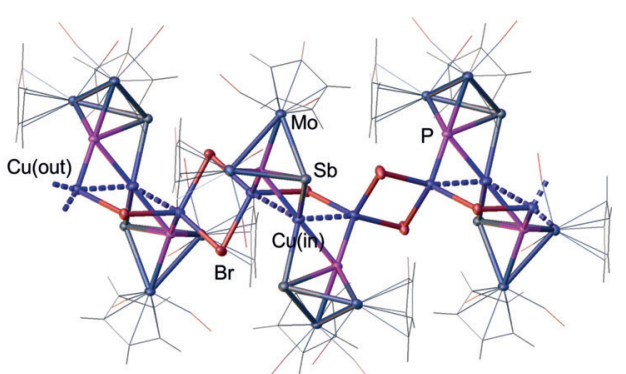

Figure 3. a) Synthesis of compounds 6-9. b) Molecular structure of 7 (6 has a similar structure; see the Supporting Information). c) Section of the 1D polymer 9 (8 has a similar structure). ${ }^{[1]}$ 
in Figure $1 \mathrm{~b}$. The removal of electron density from the $\mathrm{P}-\mathrm{Sb}$ $\sigma$-bond upon coordination of $\mathbf{2}$ to copper is also reflected in the Wiberg bond indices (WBIs). The WBI of the $\mathrm{P}-\mathrm{Sb}$ bond (0.81) is substantially lower in 7 than in $\mathbf{2}$ (1.11). The WBI of the $\mathrm{Cu}$ (out) $-\mathrm{P}$ bond (0.57) is considerably higher than for the $\mathrm{Cu}$ (in) $-\mathrm{P}$ bond (0.39), while the WBI of the $\mathrm{Cu}(\mathrm{in})-\mathrm{Sb}$ bond is only 0.29 . For the $\mathrm{Cu}$ (in) $\cdots \mathrm{Cu}$ (out) unit, a WBI of 0.29 was found; however, no pronounced orbital overlap between the two $\mathrm{Cu}$ centers was detected, but quite a few molecular orbitals show low contributions from the two copper centers in a bonding combination.

To study the effect of varying the ratio of the reactants on the reaction outcomes, we used the reaction of complex $\mathbf{2}$ with $\mathrm{CuBr}$ as an example. Two additional ratios of stoichiometry were used (1:2 and 2:3). From the first reaction, two types of crystals were obtained; red blocks (7) and dark red needles (9), with the second reaction affording exclusively $\mathbf{9}$ in good isolated yield $(45 \%)$. The X-ray structure of 9 shows a 1D polymer, which is similar in structure to $\mathbf{8}$. The coordination environments of all $\mathrm{Cu}^{\mathrm{I}}$ and $\mathrm{Br}^{-}$ions as well as the $\mathrm{Mo}_{2} \mathrm{PSb}$ moieties in $\mathbf{9}$ are similar to those described for $\mathbf{8}$, which renders 9 another example of an infinite chain of $\mathrm{Cu}_{3}$ units supported by the organometallic complex 2 .

The obtained supramolecular aggregates 3-9 demonstrate the high potential of the tetrahedral complexes $\mathrm{Mo}_{2} \mathrm{PAs}(\mathbf{1})$ and $\mathrm{Mo}_{2} \mathrm{PSb}$ (2) as heterodiatomic donor ligands in the coordination chemistry of $\mathrm{Cu}^{\mathrm{I}}$ and open the door to their use in supramolecular chemistry. Interestingly, the reactions of these complexes with $\mathrm{Cu}^{\mathrm{I}}$ afforded products different from those obtained under similar reaction conditions with their homodiatomic analogues $\left[\mathrm{Cp}_{2} \mathrm{Mo}_{2}(\mathrm{CO})_{4}\left(\mu, \eta^{2}: \eta^{2}-\mathrm{E}_{2}\right)\right](\mathrm{E}=\mathrm{P}$, As). ${ }^{[12,18]}$ This is due to the unique donor nature of $\mathbf{1}$ and $\mathbf{2}$, involving coordination via the lone pair of the $\mathrm{P}$ atom and the $\mathrm{P}-\mathrm{E}$ o-bond. In addition, the two 1D CPs 8 and 9 represent the first examples of infinite connected $\mathrm{Cu}^{\mathrm{I}}$ chains stabilized by organometallic ligands. Current investigations in this field focus on the synthesis of the new, so far non-existing heavier complexes $\left[\mathrm{Cp}_{2} \mathrm{Mo}_{2}(\mathrm{CO})_{4}\left(\mu, \eta^{2}: \eta^{2}-\mathrm{AsE}^{\prime}\right)\right]\left(\mathrm{E}^{\prime}=\mathrm{Sb}, \mathrm{Bi}\right)$ and $\left[\mathrm{Cp}_{2} \mathrm{Mo}_{2}(\mathrm{CO})_{4}\left(\mu, \eta^{2}: \eta^{2}-\mathrm{SbBi}\right)\right]$ and their potential use as linkers in supramolecular chemistry.

\section{Acknowledgements}

This work was supported by the European Research Council (Grant ERC-2013-AdG 339072).

\section{Conflict of interest}

The authors declare no conflict of interest.

Keywords: antimony - arsenic - copper - heterodiatomic units . phosphorus

How to cite: Angew. Chem. Int. Ed. 2019, 58, 12903-12907 Angew. Chem. 2019, 131, 13035-13039
[1] a) T. R. Cook, P. J. Stang, Chem. Rev. 2015, 115, 7001-7045; b) T. R. Cook, Y.-R. Zheng, P. J. Stang, Chem. Rev. 2013, 113, $734-777$; c) R. Chakrabarty, P. S. Mukherjee, P. J. Stang, Chem. Rev. 2011, 111, 6810-6918.

[2] a) S. Evariste, A. M. Khalil, M. E. Moussa, A. K.-W. Chan, E. Y.H. Hong, H.-L. Wong, B. L. Guennic, G. Calvez, K. Costuas, V. W.-W. Yam, C. Lescop, J. Am. Chem. Soc. 2018, 140, 12521 12526; b) M. Elsayed Moussa, S. Evariste, B. Krämer, R. Réau, M. Scheer, Angew. Chem. Int. Ed. 2018, 57, 795-799; Angew. Chem. 2018, 130, 803-807; c) D. Yadav, R. K. Siwatch, G. Mukherjee, G. Rajaraman, S. Nagendran, Inorg. Chem. 2014, 53, 10054-10059; d) A. Serpe, F. Artizzu, L. Marchiò, M. L. Mercuri, L. Pilia, P. Deplano, Cryst. Growth Des. 2011, 11, 1278-1286; e) F. A. Cotton, E. V. Dikarev, M. A. Petrukhina, Angew. Chem. Int. Ed. 2001, 40, 1521-1152; Angew. Chem. 2001, 113, 1569-1571.

[3] a) R. H. Horikoshi, T. Tominaga, T. Mochida, Cryst. Growth Des. 2018, 18, 5089-5098; b) X.-L. Zhao, W.-Y. Sun, CrystEngComm 2014, 16, 3247-3258; c) Y. Matano, T. Miyajima, N. Ochi, T. Nakabuchi, M. Shiro, Y. Nakao, S. Sakaki, H. Imahori, J. Am. Chem. Soc. 2008, 130, 990-1002; d) B. Nohra, S. Graule, C. Lescop, R. Réau, J. Am. Chem. Soc. 2006, 128, 3520-3521; e) M. Oh, C. L. Stern, C. A. Mirkin, Inorg. Chem. 2005, 44, 2647-2653.

[4] a) K. Škoch, I. Císařová, J. Schulz, U. Siemeling, P. Štěpnička, Dalton Trans. 2017, 46, 10339-10354; b) J. Wachter in Comprehensive Inorganic Chemistry II, Vol. 1 (Eds.: J. Reedijk, K. Poeppelmeier), Elsevier, Amsterdam, 2013, pp. 933-952.

[5] a) K. H. Whitmire, Coord. Chem. Rev. 2018, 376, 114-195; b) M. Scheer, Dalton Trans. 2008, 4372-4386.

[6] a) M. E. Moussa, M. Fleischmann, E. V. Peresypkina, L. Dütsch, M. Seidl, G. Balázs, M. Scheer, Eur. J. Inorg. Chem. 2017, $3222-$ 3226; b) M. Fleischmann, S. Welsch, E. Peresypkina, A. V. Virovets, M. Scheer, Chem. Eur. J. 2015, 21, 14332-14336; c) M. Fleischmann, F. Dielmann, L. J. Gregoriades, E. Peresypkina, A. V. Virovets, S. Huber, A. Y. Timoshkin, G. Balázs, M. Scheer, Angew. Chem. Int. Ed. 2015, 54, 13110-13115; Angew. Chem. 2015, 127, 13303-13308; d) M. Scheer, L. J. Gregoriades, M. Zabel, J. Bai, I. Krossing, G. Brunklaus, H. Eckert, Chem. Eur. J. 2008, 14, 282-295.

[7] a) C. Heindl, E. Peresypkina, A. V. Virovets, I. S. Bushmarinov, M. G. Medvedev, B. Krämer, B. Dittrich, M. Scheer, Angew. Chem. Int. Ed. 2017, 56, 13237-13243; Angew. Chem. 2017, 129 , 13420 -13426; b) C. Heindl, E. V. Peresypkina, A. V. Virovets, W. Kremer, M. Scheer, J. Am. Chem. Soc. 2015, 137, $10938-$ 10941; c) M. Scheer, A. Schindler, R. Merkle, B. P. Johnson, M. Linseis, R. Winter, C. E. Anson, A. V. Virovets, J. Am. Chem. Soc. 2007, 129, 13386-13387; d) J. Bai, A. V. Virovets, M. Scheer, Science 2003, 300, 781-783.

[8] H. Brake, E. Peresypkina, C. Heindl, A. V. Virovets, W. Kremer, M. Scheer, Chem. Sci. 2019, 10, 2940-2944.

[9] S. Welsch, C. Gröger, M. Sierka, M. Scheer, Angew. Chem. Int. Ed. 2011, 50, 1435-1438; Angew. Chem. 2011, 123, 1471-1474.

[10] a) C. Heindl, E. Peresypkina, D. Lüdeker, G. Brunklaus, A. V. Virovets, M. Scheer, Chem. Eur. J. 2016, 22, 2599-2604; b) M. Fleischmann, S. Welsch, E. V. Peresypkina, A. V. Virovets, M. Scheer, Chem. Eur. J. 2015, 21, 14332-14336; c) F. Dielmann, C. Heindl, F. Hastreiter, E. V. Peresypkina, A. V. Virovets, R. M. Gschwind, M. Scheer, Angew. Chem. Int. Ed. 2014, 53, $13605-$ 13608; Angew. Chem. 2014, 126, 13823-13827; d) M. Scheer, L. J. Gregoriades, A. V. Virovets, W. Kunz, R. Neueder, I. Krossing, Angew. Chem. Int. Ed. 2006, 45, 5689-5693; Angew. Chem. 2006, 118, 5818-5822; e) J. Bai, A. V. Virovets, M. Scheer, Angew. Chem. Int. Ed. 2002, 41, 1737-1740; Angew. Chem. 2002, 114, 1808-1811.

[11] a) M. Elsayed Moussa, E. Peresypkina, A. V. Virovets, D. Venus, G. Balázs, M. Scheer, CrystEngComm 2018, 20, 7417-7422; 
b) M. Elsayed Moussa, B. Attenberger, E. V. Peresypkina, M. Scheer, Dalton Trans. 2018, 47, 1014-1017; c) M. E. Moussa, M. Seidl, G. Balazs, M. Zabel, A. V. Virovets, B. Attenberger, A. Schreiner, M. Scheer, Chem. Eur. J. 2017, 23, 16199-16203; d) M. Elsayed Moussa, B. Attenberger, E. V. Peresypkina, M. Fleischmann, G. Balázs, M. Scheer, Chem. Commun. 2016, 52 , 10004-10007; e) B. Attenberger, S. Welsch, M. Zabel, E. Peresypkina, M. Scheer, Angew. Chem. Int. Ed. 2011, 50, 11516-11519; Angew. Chem. 2011, 123, 11718-11722.

[12] a) H. Krauss, G. Balázs, M. Bodensteiner, M. Scheer, Chem. Sci. 2010, 1, 337-342; b) L. J. Gregoriades, H. Krauss, J. Wachter, A. V. Virovets, M. Sierka, M. Scheer, Angew. Chem. Int. Ed. 2006, 45, 4189-4192; Angew. Chem. 2006, 118, 4295-4298.

[13] H. V. Ly, M. Parvez, R. Roesler, Inorg. Chem. 2006, 45, 345-351.

[14] a) C. Schwarzmaier, M. Bodensteiner, A. Y. Timoshkin, M. Scheer, Angew. Chem. Int. Ed. 2014, 53, 290-293; Angew. Chem. 2014, 126, 295-299; b) C. Schwarzmaier, A. Noor, G. Glatz, M. Zabel, A. Y. Timoshkin, C. C. Cummins, R. Kempe, M. Scheer,
Angew. Chem. Int. Ed. 2011, 50, 7283-7286; Angew. Chem. 2011, 123, 7421-7424.

[15] a) J. E. Davies, M. J. Mays, P. R. Raithby, G. P. Shields, P. K. Tompkin, A. D. Woods, J. Chem. Soc. Dalton Trans. 2000, $1925-$ 1930; b) J. E. Davies, L. C. Kerr, M. J. Mays, P. R. Raithby, P. K. Tompkin, A. D. Woods, Angew. Chem. Int. Ed. 1998, 37, $1428-$ 1429; Angew. Chem. 1998, 110, 1473-1475.

[16] M. Stollenz, Chem. Eur. J. 2019, 25, 4274-4298, and references therein.

[17] In case of disorder, only the major part of the disorder is depicted for clarity.

[18] M. Scheer, L. Gregoriades, J. Bai, M. Sierka, G. Brunklaus, H. Eckert, Chem. Eur. J. 2005, 11, 2163-2169.

Manuscript received: June 6, 2019

Accepted manuscript online: July 17, 2019

Version of record online: August 19, 2019 